資 料

\title{
全国食肉衛生検查所協議会病理部会研修会（第 70 回） における事例報告（II）
}

\author{
日 名 由紀子† \\ 全国食肉衛生検査所協議会病理部会事務局千葉県東総食肉衛生検査所 \\ （干 289-2504 旭市ニ 5908-3）
}

Proceeding of the Slide-Conference held by Pathology Group of the National Meat Sanitary Inspection Office Council (70th) Part 2

Yukiko HINA $^{\dagger}$

Chiba Prefectural Tousou Meat Sanitary Inspection Office, 5908-3 Ni, Asahi-city, 289-2504, Japan

$(2018$ 年 6 月 5 日受付 $\cdot 2018$ 年 11 月 5 日受理)

\section{8 豚}

症例 : 豚 (雑種), 去勢, 6 力月齢.

〔高橋 巧 (宮城県) 〕

臨床的事項：一般畜として搬入され，特に異常は認め られなかった。

内臓所見：肝臓全葉に $1 \sim 3 \mathrm{~mm}$ 程度の灰白色結節が 多発していた。結節は表面に隆起しているものや，実質 内に入り込んでいるものが認められた．肝リンパ節は腫 大し，最大 $4 \times 3 \times 2 \mathrm{~cm}$, 腸間膜リンパ節は全体的に腫 大し，最大 $6 \times 2 \times 2 \mathrm{~cm}$ 程度であった。割面は膨隆し， 一部では中心部に灰白色結節が認められた。さらに，胃 リンパ節も腫大していた。 そのほかの臓器, リンパ節に 著変は認められなかった。

組織所見：肝臓の灰白色結節では, 類上皮細胞, 多核 巨細胞, 好酸球, リンパ球から成る肉芽腫性炎が認めら れた. 肝組織の一部で類洞の拡張, 結合織の増生, リン パ球の集蔟が認められた．肝リンパ節でも肝臓の灰白色 結節と同様の肉芽腫性炎が認められた．腸間膜リンパ節 では肉芽腫性炎のほか, 一部で石灰化した領域も認めら れた. 肝臓, 肝リンパ節, 腸間膜リンパ節では, チール・ ネルゼン染色により赤色桿菌が, オーラミン B・ローダ ミン $\mathrm{G}$ 重染色により蛍光下（励起波長 $520 \mathrm{~nm}$, 吸収波
長 560nm）で発光する桿菌がそれぞれ認められた.

診断名：抗酸菌の検出された豚の多病巣性肉芽腫性肝 炎（豚抗酸菌症）

9 牛 の 脾 臓

[太島勇気 (神奈川県)]

症例 : 牛 (黒毛和種), 雌, 160 力月齢.

臨床的事項：特に異常は認められなかった.

肉眼所見：脾臟の壁側面に 4 個の腫瘤（1) $12 \times 11.5$ $\times 4.3 \mathrm{~cm}$, (2) $19 \times 15 \times 4.3 \mathrm{~cm}$, (3) $7.5 \times 7 \times 2.7 \mathrm{~cm}$, (4) 13 $\times 10 \times 2.9 \mathrm{~cm} ）$ が認められた。これらの腫瘤は被膜に覆 われ，脾蔵表面から突出していた，割面では固有構造と の境界には被膜が存在しないものの, 比較的明瞭であっ た。腫瘤の割面は膨隆していた。腫瘤は小豆色を呈し, 脾材はわずかに残存していた。 その他の臓器には, 特に 異常は認められなかった。

組織所見：腫瘤部は,ほぼ脾臓組織に類似していた が, 腫瘤部と固有構造には次のような違いが認められ た.

(1)腫瘤部は赤脾髄が多くを占め, 白脾髄はわずかに残 存するのみであった。(2)脾洞は腫瘤部が固有構造より, より多くの赤血球を含有していた. (3)脾柱は腫瘤部にお

\footnotetext{
$\dagger$ 連絡責任者：日名由紀子(千葉県東総食肉衛生検査所) 干 289-2504 旭市二 5908-3 0479-62-2887 FAX 0479-62-2757

E-mail : tousyokken@mz.pref.chiba.lg.jp

$\dagger$ Correspondence to : Yukiko HINA (Chiba Prefectural Tousou Meat Sanitary Inspection Office) 5908-3 Ni, Asahi-city, 289-2504, Japan TEL 0479-62-2887 FAX 0479-62-2757 E-mail: tousyokken@mz.pref.chiba.lg.jp
} 
いて，固有構造より少なくなっていた（4)赤脾䯣の細網 線維は腫瘤部に抢いて, 固有構造より少なくなってい た。肉眼的には境界は比較的明膫であったが，組織学的 には固有構造との境界は不明瞭であった。白脾髄には, 固有構造と同様に中心動脈が認められるものもあった.

診断名 : 牛の脾臟の過誤腫

\section{0 豚の腹腔内腫瘍}

〔池田 稔 (大分県)

症例：豚 (雑種), 雌, 推定 3 歳.

臨床的事項：一般健康畜として搬入. 著変なし.

肉眼所見：腹胿内に，凹凸のある $70 \times 60 \times 40 \mathrm{~cm}$ 大 の乳白色腫瘤を認めた，腫瘤は厚い被膜で覆われ，腹膜 及び大小腸と癒着していたが，容易に剥離できた。腫瘤 割面は乳白色, 充実性で膨隆し, 不規則, 分葉状を呈し, 一部で出血を伴う暗赤色で脆弱な壊死巣を認めた。 ま た，腫瘤内部に腫大した右腎を認めた，右腎は腎門部が 腹腔内腫瘤と連続する同様の腫瘤で满たされていた。皮 質及び髄質は圧排されていたが，固有構造は残存してい た。また，肺に大豆大の白色腫㢚を散在性に認めた，左 腎，その他の腹腔内臟器及び全身リンパ節には異常を認 めなかった.

組織所見：腹腔内腫瘤は，結合組織によって不規則に 分画され，胞巣状を呈し，胞巣内部では腫瘍細胞が腺管 状または充実性に増殖していた，腺管状構造をとる腫瘍 細胞は，立方状から円柱状で，細胞質に富み，比較的大 型で明るい核を有していた。また，単層から重層に配列 し, 分化度の異なる腺管状構造をとって増殖していた。 一部で原始系球体様構造もみられた。 また, 腺管状構造 の間隙には，大小不同，類円形で細胞質にそしく，クロ マチンに富んだ核をもつ腫瘍細胞が充実性に增殖してい た. 腺管状構造をとる腫瘍細胞はサイトケラチン (AE1/ $\mathrm{AE} 3$ ，ニチレイ）に陽性を示し，間隙を埋める腫瘍細胞 はビメンチン（ニチレイ）に陽性を示した，肺腫瘤は， 結合組織によって胞巣状に分画され, 腹胿内腫瘤と同様 の組織形態が認められた。

診断名：豚の腎芽腫（上皮型）

\section{1 牛の小腸の腫瘤}

〔佐々木菜保子 (岡山市) 〕

症例：牛 (黒毛和種), 雌, 64 力月齢.

臨床的事項：「腸閉塞」との診断名で病畜として搬入 され，解体検查において腸重積が認められた。

肉眼所見 : 小腸に径数 $\mathrm{cm}$ のやや硬結感のある腫瘤が 多発しており，腫瘤は小腸粘膜内側から内腔へポリープ 状に隆起していた，腫瘤割面は，白色，充実性で，分画 された構造が認められた。筋肉, その他臟器について肉 眼的に異常は認められなかった。
組織所見：腫瘍細胞は結合組織によって外側組織と分 画され, 細胞密度の高い Antoni $\mathrm{A}$ 領域及び細胞密度の 低い Antoni B 領域をもちながら増殖し, Antoni A 領域 においては，柵状配列及び Verocay 小体が認められた。 腫瘍細胞は, 紡鍾形〜不整形で弱好酸性の細胞質をわず かにもち, 核は大小不同, 円形～楕円形で，核分裂像は 認められなかった，免疫染色では腫瘍細胞は, ビメンチ ン, S100 蛋白, SOX10 に陽性を示し, NSE に弱陽性を 示した.

診断名：小腸の末梢神経鞘腫瘍

討議：末梢神経鞘腫の場合, 神経に沿って多発するこ とがあるため, 多発していても悪性とは限らないとの意 見があった。

\section{2 牛の子宮の腫瘤}

〔阿部あすみ (杤木県) 〕

症例: 牛 (ホルスタイン種), 雌, 178 カ月齢.

臨床的事項：一般畜として搬入され，削瘦を認めた。

肉眼所見: 子宮角頭側漿膜面及び卵管采付近に直径 $6 \mathrm{~cm}$ 大の腫瘤を 1 個ずつ認めた，子宮角腫瘤（1）の 割面は淡桃色〜乳白色で膨隆し，白色線維性の間質によ る無秩序な分画を認めた。卵管采付近の腫瘤（2)）の割 面は乳白色でやや膨隆し, 肉眼的に均一な組織から成っ ていた，子宮内膜や左右卵巣に異常はなく，その他の臓 器に関連する異常も認められなかった。

組織所見：腫瘤(1)では紡鍾形の腫瘍細胞が, 不規則に 交差する束状の構造をとって増殖していた，核及び細胞 の異型性は低く, 分裂像は認められなかった。免疫染色 では, 腫瘍細胞の細胞質は Desmin 及び $\alpha$ SMA に強陽 性を示し, 一部の腫瘍細胞の核及び細胞質が S-100 蛋 白に弱陽性を示した。腫瘤(2は線維性の被膜で覆われ， 内部は線維性の間質で胞巣状に仕切られていた。 円形〜 棈円形の核をもつ紡鍾形の腫瘍細胞が胞巣壁に沿って垂 直に配列していた，大部分の腫瘍細胞では，核の大小不 同や異型性が低かったが，時折異型性の高い巨大な核を もつ腫瘍細胞や分裂像が散見された。一部の胞巣の内部 には, PAS 反応に陽性を示し, 同心円構造をもつ物質 が認められた，免疫染色では，腫瘍細胞の細胞質が Inhibin- $\alpha$ に, 細胞質及び核が S-100 蛋白に陽性を示 した.

診断名：(腫瘤(1)) 牛の子宮平滑筋腫

（腫瘤(2)）牛の卵巣外のセルトリ細胞腫

討議：卵巣外に発生するセルトリ細胞腫の由来とし て, 発生過程で遺残した生殖腺や, 排卵時に卵巣外にこ ぼれた顆粒膜細胞などが考えられた。 
症例：牛 (ホルスタイン種), 雌, 5 歳

臨床的事項：股関節脱臼との診断名で病畜として搬 入.

肉眼所見：左右肺葉内及び胸膜面に拇指頭大～鶏卵大 の腫瘤を多数認めた，腫瘤は硬結感があり，割面は乳白 色，充実性で，周辺組織との境界は明瞭な部分と不明瞭 な部分とが認められた，気管気管支リンパ節，縦隔リン パ節，胸骨リンパ節，肝門リンパ節，第四胃周囲のリン パ節，腎門リンパ節，内腸骨リンパ節の腫大，硬化を認 めた。これらの割面では，壊死や出血を認めた。

組織所見：肺腫瘤では，類円形の核と少量の細胞質を 有する小型円形細胞が充実性に増殖し，一部線維性結合 組織で疎に区画される領域も認めた。腫瘍細胞の核染色 質は繊細で，クロマチン結節に富み，明瞭な核仁を有し ていた，核分裂像も散見された。これらのほかに，やや 濃染する核と好酸性の広い細胞質を有する円形の腫瘍細 胞や, 細胞質が好酸性で細長く, 細胞質内に明暸な横紋 がみられ，二核あるいは多核化した筋管細胞様の腫瘍細 胞も認められた。腫瘍細胞は周囲肺組織に浸潤性に増殖 しており，肺胞腔から細気管支内に突出する部分も認め られた。PTAH 染色では腫瘍細胞内の線維は濃青色に 染色され，横紋が明瞭に認められた。腫大・硬化してい た各リンパ節は，同様の腫瘍細胞により置換されてい た。免疫染色では，腫瘍細胞はVimentin，Desmin， Myogenin 及び MyoD1に陽性, Cytokeratin (AE1/ AE3), $\alpha$-SMA に除性を示した.

診断名：横紋筋肉腫（胎児型）の肺転移（肺, 全身リ ンパ節への転移を伴った牛の横紋筋肉腫）

討議：転移巣の組織所見から形態学的な分類名として よいのかとの指摘があったが，組織診断名のみであれば よいとの助言があった。 なお，原発部位は不明であった。

\section{4 豚 の 肺}

〔稲葉夏深 (富山県) 〕

症例 : 豚 (雑種), 去勢, 6 力月齢.

臨床的事項：著変は認められなかった.

肉眼所見：肺胸膜及び割面に $1 \sim 3 \mathrm{~mm}$ 大，不整形の 黒色斑が散在していた，黒色斑の表面は平滑で，硬結感 はなかった。黑色斑以外に胸膜炎と肺炎を認めたが，そ の他の内臓, 眼球, 口腔, 表皮, 枝肉及び全身のリンパ 節に著変は認められなかった。

組織所見：肺胞壁及び血管周囲に褐色色素顆粒を有す る細胞の集簇を認めたが，肺組織の固有構造は保たれて いた．色素を有する細胞は類円形か，多角形または紡錘 形のような不整形を示し，いずれも異型性は低く，核分 裂像は認められなかった。顆粒はフォンタナ・マッソン
染色で黒染し, 過マンガン酸カリウムシュウ酸法で漂白 された. 抗 S-100 蛋白に対する免疫染色では, 不整形 の褐色色素含有細胞は陽性を示し, 類円形の褐色色素含 有細胞の多くは㓌性を示した.

診断名：豚の肺のメラノーシス

\section{5 めん羊の全身性黒色色素沈着}

〔高橋広志 (秋田市) 〕

症例：めん羊 (サフォーク), 雄, 7 カ月歯令.

臨床的事項：著変認めず.

肉眼所見：第一〜第二頸椎の椎孔，椎体及び棘突起， 並びに第二胸椎, 第四胸椎及び第一腰椎の椎体に境界不 明瞭な黒色病変を認め, 頸椎周囲の筋肉にも広がってい た. また, 延髄〜腰髄の軟膜, くも膜及び硬膜において も，広範に黒色病変を認めた。病変は硬膜より軟膜，〈 も膜で重度であり, 最も重度であった第二頸髄では脊䯣 白質に及び, 神経根の黑色化も認められた. 左右肺, 肝 臓において針頭大〜拇指頭大の円形黒色斑が散在し, 割 面で深部に及んでいた。 その他, 左心乳頭筋, 脾臓, 左 腎臓, 副腎, 胆囊, 横隔膜に黒色病変を認めた。いずれ の部位でも隆起や腫瘤形成は認められず, 皮下組織, 躯 幹リンパ節に黒色病変は認められなかった。

組織所見：骨髄では，黒色色素顆粒を含む細胞が脂肪 細胞と混在し，造血組織内にも浸潤していた。同細胞の 形態は類円形〜不整形で淡明の円型核を有していた。延 髄及び脊髄では, 軟膜, くも膜及び白質の血管周囲, 神 経線維に沿って色素顆粒細胞を認めた. 同様の細胞が, 肺では肺胞中隔, 肝臓では門脈域を中心に浸潤してい た。その他の黒色病変部においても, 色素顆粒細胞の浸 潤を認めた。いずれの部位でも核の大小不同，異型性及 び分裂像は認められず, 組織の固有構造は保持されてい た. 色素顆粒は過マンガン酸カリウムシュウ酸法で漂白 された。 また，免疫染色により色素顆粒細胞の大半が抗 S100 蛋白陽性, 抗リゾチーム陰性を示したため, 同細 胞はメラノサイト由来と考えられた。

診断名：めん羊の第二頸椎のメラノーシス（めん羊の 全身性メラノーシス)

\section{6 豚の全身性腫瘍}

〔日比野拓已 (名古屋市)〕

症例：豚 (雑種), 雌, 約 6 力月齢.

臨床的事項：著変なし.

肉眼所見：肝臓は約 2 倍に腫大し, 直径 $1 \sim 2 \mathrm{~cm} の$ 乳白色髄様結節を表面及び実質内に多数認めた。結節の 断面は乳白色，無構造であった。腎蔵実質内においても 直径 $2 \sim 3 \mathrm{~mm}$ 程度の乳白色髄様結節を数個認めた. 脾 臓は実質内に砂粒大の白色斑の散在を認め, 割面は膨隆 していた，気管気管支リンパ節及び胃リンパ節は鷄卵大 


\section{全国食肉衛生検査所協議会病理部会研修会（第 70 回）における事例報告（II）}

に，腋窩リンパ節はクルミ大に腫脹していた．頸椎から 尾椎にかけて，脊柱骨髄の白色化がみられた。構造変化 は伴わず，時間経過とともに通常の暗赤色に変化した． その他のリンパ節，内臓及び枝肉に著変はなかった。

組織所見：肝臓及び腎臟のスタンプ標本において，リ ンパ芽球様細胞を含む多様な白血球を認めた。肝臟の組 織標本では，打もに小葉間結合組織から小葉内にリンパ 芽球様細胞が浸潤していた。腎臓の結節はリンパ芽球様 細胞で構成され，スターリースカイ像が散見された。脾 臟実質内にリンパ芽球様細胞が確認された。脾，胃，気 管気管支及び腋窩リンパ節は固有構造が消失していた。
脊柱骨髄にはリンパ芽球様細胞が充満していた。リンパ 芽球様細胞は, 明嘹な核仁を複数有する淡明, 類円形の 大型の核及び好塩基性の細胞質を有する中型〜大型の細 胞であった，免疫染色では，リンパ芽球様細胞は CD20 (Acris Antibodies) に陽性, CD3（Dako）に陰性であっ た.

診断名：リンパ性白血病 (B 細胞性) の肝病変

討議：リンパ芽球様細胞の増殖は骨䯣を主体としてい ると考えられたため, 診断名をリンパ性白血病とした. 骨䯣の色調が白色から暗赤色に変化した原因はへモグロ ビン等の酸化ではないかと意見が出た. 